also recognized that the development of electronic devices for storage and retrieval of information must be a main object of study in the new Library, and research was already proceeding into the possibility of collecting abstracts in punched tape form. Such a method might solve many of the problems of overlapping and delay in abstracts, and he thought the multiple use of the same abstracts should be encouraged rather than repeated abstracting of the same papers. In interpreting the amendment as implying a statutory obligation to provide a comprehensive national scientific abstracting service, which he did not regard as helpful, the Earl of Dundee was strongly supported by the Earl of Crawford, who argued that it would be better to await the outcome of the present enquiries, and regarded the proposal as damaging to the Library and a retrograde step. The amendment was, by leave, withdrawn.

\section{The Commonwealth Development Bill}

Is moving the second reading of the Commonwealth Development Bill in the House of Commons on June 19, the Under-Secretary of State for Commonwealth Relations, Mr. J. Tilney, said that the Bill amended the Overseas Resources Development Act, 1959, and the Colonial Development and Welfare Act by returning to the sphere of activity of the Colonial Development Corporationnow to be renamed the Commonwealth Development Corporation-all Commonwealth territories within its scope when the Corporation was established in 1948. In accordance with powers conferred under the Bill, the Secretary of State will instruct the Corporation to seek his prior approval before starting operations in an independent country and that approval will only be given with the agreement of the Government concerned. It is not proposed to raise the amount which the Corporation can borrow from the Treasury above the limit of $£ 130$ million: net advances outstanding amount to $£ 92$ million, and in the past ten years borrowings have averaged less than $£ 10$ million per annum. Mr. Tilney said that the Corporation welcomed the policy embodied in the Bill.

On the colonial development and welfare side, the Bill extended the period in which such schemes could be made and Exchequer loans approved from March 31, 1964, to March 31,1966 , and increased from $£ 315$ million to $£ 340$ million the amount which may be spent on schemes under Section I of the 1959 Act. About $£ 43.5$ million remained unspent at March 31,1963 , so that about $£ 68.5$ million would be available for the three years 1963-66, and the provision for Exchequer loans was increased from $£ 100$ million to $£ 105$ million, permitting further issues of $£ 41$ million. Mr. Tilney pointed out that expenditure on research and development was now financed by the Department for Technical Co-operation and said that this change did not imply any decrease in research for the benefit of colonial territories. While the Bill was welcomed generally, Opposition speakers criticized the provisions as inadequate, but in replying on the debate for the Government, the Under-Secretary of State for the Colonies, Mr. N. Fisher, put the total of Government aid overseas during the next three years at $£ 180-200$ million a year.

\section{Transition from Primary to Secondary Education}

IN a written answer in the House of Commons on June 17, the Minister of Education, Sir Edward Boyle, stated that when the Central Advisory Council for Education (England) had completed its present task, he proposed to reconstitute it with the following terms of reference: To consider primary education in all its aspects and the transition from primary to secondary education. In due course, he. would ask the Central Advisory Council for Education (Wales) to consider the Welsh aspects of this enquiry and he was arranging for some common membership of the two Councils. Lady Plowden had accepted his invitation to become the next chairman of the Council, and the present chairman, Mr. J. Newson, had agreed to serve as deputy chairman of the reconstituted Council.

\section{English Clearly Expressed}

Prof. R. Hoggart's inaugural locture, "Schools of English and Contemporary Society", delivered at the University of Birmingham on February 8, is concerned with emphasizing the practical importance and significance of a love and respect for language - which he regards as a prime duty of a school of English to foster (Birmingham: The University, 1963. 2s. 6d.). He insists that English has to do with exploring human experience in all its complexity and flux, and what he has to say about the changing meaning of words and the necessity of defining the meaning of words in the context in which they are used is highly pertinent to the scientist and his task of interpretation and exposition, whether it is a matter of exposition to his follow scientists or to a wider public. Prof. Hoggart gives clear warning of the dangers which attend the careless use of words irrespective of the meaning which is likely to be attached to them by particular audiences or in particular circumstances. His lecture is as apposite in the context of discussions on the content of a general education as it is to the proper functions and value of a school of English.

\section{United States Readings on Development}

A Selected List of United States Readings on Development (Pp. xvii + 363. Washington, D.C.: Agency for International Development. Obtainable from U.S. Government Printing Office, 1963. 1.25 dollars), prepared for the United Nations Conference on the Application of Science and Technology for the Benefit of the Less Developed Areas by S. M. Katz and F. McGowan, of the University of Pittsburgh, is a companion volume to the twelve volumes of United States papers prepared in connexion with the Conference (see Nature, 198, 250; 1963). Its thirteen chapters, containing almost 1,200 references, cover the regional planning experience of the Tennessee Valley Authority and Puerto Rico, production and marketing policies of great industrial enterprises, and the role of universities in concerting research and education in the service of human welfare. There is a short chapter on scientific and development policies, which includes sections on society and science and Government and science, but this is rather too limited in scope to be of service to any but the most elementary student of such subjects, though the chapter lists some references which are not generally known in the United Kingdom.

\section{The Universities Federation for Animal Welfare}

The Universities Federation for Animal Welfare has issued an interesting pamphlet setting out briefly some of the immediate interests that are given attention (Some Things Done, Being Done, and to be Done. Pp. 6. London: The Universities Federation for Animal Welfare, 1963). Included are: experiments on animals; pain in animals; the gin trap in Britain and overseas; cruel poisons; irresponsible shooting; whaling; correct technique for the electrocution of dogs and cats; tortoise trade; farm animals; anæsthesia; bull-fighting. Some indication of the manner in which the Federation undertakes its work is also given.

\section{The Association of Consulting Scientists}

As the annual general meeting of the Association of Consulting Scientists held in London recently the following honorary officers and members of council were elected: Chairman, Mr. F. G. Sarel Whitfield (Avebury Research Laboratories Ltd.); Vice-Chairman, Dr. H. H. Chambers (Sondes Place Research Laboratories Ltd.); Honorary Treasurer, Dr. G. W. Ferguson (Parry and Ferguson); Honorary Secretary, Mr. W. H. Stevens (Geochemical Laboratories); Members of Council, Dr. G. P. L. Miles, Mr. H. Pritehard, Mr. J. A. Radley (J. A. Radley Labora- 